\title{
Experimental Study on Configuration and Spacing of Screw Pile Group Effect Subjected to Lateral Cyclic Loading
}

\author{
Azhar S. Ibrahim ${ }^{1, a}$, Hassan O. Abbas ${ }^{1, b^{*}}$ and Omar K. Ali ${ }^{2, c}$ \\ ${ }^{1}$ Civil Engineering Department, University of Diyala, Baqubah, Diyala, Iraq. \\ ${ }^{2}$ Ministry of Education, Directorate of school buildings, Baqubah, Diyala, Iraq. \\ aAzharsubhi19@gmail.com, btemimi71@yahoo.com, oomar.alzuhairy.oa@gmail.com
}

\begin{abstract}
Despite the great development in the manufacture of the helical pile and the development of their use, especially in transmission towers and wind turbines, there is little research on their lateral behavior. In this laboratory study investigate the behavior of screw piles group $(2 \times 1)$ and $(1 \times 2)$ with the spacing to the diameter of helix ratio $(\mathrm{S} / \mathrm{Dh}=1.5,3$, and 4.5$)$ having a diameter $(10 \mathrm{~mm})$ and embedded length to diameter ratio $(\mathrm{L} / \mathrm{D}=40)$ by using single and double helix embedded in soft clay and extend to stiff clay under a cyclic lateral load of frequency $(0.2 \mathrm{~Hz})$. The results showed that increasing the distance between the piles had a great effect on increasing the lateral resistance. the increase of pile spacing in the groups from $(1.5 \mathrm{Dh})$ to $(3$ and $4.5 \mathrm{Dh})$ increases the lateral resistance about $34-38 \%$ and $50 \%$ respectively. Also, from result showed that the group $(2 \times 1)$ gave a lateral resistance more than the group $(1 \times 2)$ about $11 \%$ for single helix and about $6 \%$ for a double helix, and for the same spacing and configuration the screw pile with double helix gives an increase in lateral resistance about $5-10 \%$ from the single helix.
\end{abstract}

Keywords: Screw pile; helical pile; cyclic loading; lateral load; spacing; configuration

\section{Introduction}

Screw piles or helical piles are deep foundation elements used to resist forces exerted by tension, axial compression, and lateral loading [1]. Screw piles consist of one or more circular helical plates (or flanges) welded onto a solid steel shaft or hollow [2]. Screw piles are installing into the soil by applying a torque at the head of the shaft of the pile, which produce penetrate the helix or helices to the ground in circular motion [3]. During the past few years, great progress has been made in installing and increasing the axial capabilities of helical piles. Currently, using helical piles with axial capacities over $3 \mathrm{MN}$, the availability of high torque rotary heads has made it easier to install screw piles of large diameter in competent soils such as very stiff clay and very dense sand. Helical piles of diameters more than $508 \mathrm{~mm}$ have been successfully installed into hard soils [4].

Recently helical piles are used in many applications in civil engineering such as bridges, commercial and residential buildings, foundations of wind turbines, machine foundations, transmission towers, marine anchors, and pier supports, these structure in addition to axial load subjected to lateral static and cyclic loading generated by a wave, current, and wind, etc. [5, 6]. So, the lateral static and cyclic resistances have become a large component of their overall capacity. Previously there are several studies on the lateral behavior of helical piles, including theoretical and laboratory studies [8-10], field studies [4, 11,12], and numerical studies [13]. There are also some local studies about screw piles in Iraqi soils [14-17] in addition to some studies about the effect of cyclic lateral loads on traditional piles in Iraqi soils [18-21].

However, the studies on the behavior of screw pile group under lateral cyclic load in clay were scarce. This study was conducted on soft clay and stiff clay multilayer because this soil covers large parts of central and southern Iraq [15]. Soft clay distinguished by low undrained shear strength 20 to $40 \mathrm{kPa}$ and high in compressive Cc 0.19 to 0.44 and stiff clay is distinguished by the range of undrained shear strength between 100 to $150 \mathrm{kPa}$ [22]. The parameters of this study are the configuration of pile group, the effect of spacing between piles, the effect of helix number, the effect of cyclic load ratio, and the effect of several cyclic. 


\section{Material Used}

Soil. The clay soil used in this study was taken from the city of Baquba, Al-Bawiyah region, near the brick factories, from depths of 2-4 $\mathrm{m}$ below the surface of the earth. All initial tests were carried out in the soil laboratory of the College of Engineering, Diyala University. The properties of clay soil are shown in Table 1.

Table 1. Summary properties of soft clay soil.

\begin{tabular}{|c|l|c|c|}
\hline Item & Properties & Value & Specification \\
\hline 3 & Liquid limit (LL) \% & 37 & ASTM D-4318 \\
\hline 4 & Plastic limit (PL) \% & 23 & ASTM D-4318 \\
\hline 5 & Plasticity index (IP) \% & 14 & - \\
\hline 6 & Specific gravity (Gs) & 2.85 & ASTM D-854 \\
\hline 7 & Percent of clay & 52.7 & ASTM D-422 \\
\hline 8 & Percent of silt & 43.3 & ASTM D-422 \\
\hline 9 & Percent of sand & 4 & ASTM D-422 \\
\hline 10 & Unified soil classification system (USCS) & $\mathrm{CL}$ & ASTM D-2487 \\
\hline 11 & Optimum moisture content (O.M.C) $\%$ & 18 & ASTM D-698 \\
\hline 12 & Maximum unit weight $\left(\mathrm{kN} / \mathrm{m}^{3}\right)$ & 16.75 & ASTM D-698 \\
\hline
\end{tabular}

Soil Container. Two cylindrical containers locally manufactured from steel with a thickness of $4 \mathrm{~mm}$ are used in this study have a diameter of $50 \mathrm{~cm}$ and height of $65 \mathrm{~cm}$. The container was painted with two layers to resist corrosion. The base of the container consists of six wheels for free movement in different directions. The dimensions of the container are chosen to avoid the boundaries affecting the lateral behavior of the group during the test. To avoid the effect of boundaries, the ratio between the width of the container to the lateral dimension of the pile group must be greater than 3 , and the ratio between the height of the container to the embedded depth of the piles in the soil greater than 1.625 $[23]$.

Pile and Pile Cap. Screw pile with length $440 \mathrm{~mm}$ and diameter $10 \mathrm{~mm}$ is manufactured from solid steel. The pile consists of a single and double helix plate with constant spacing between helix $60 \mathrm{~mm}$. The diameter of the helix $20 \mathrm{~mm}$, thickness $2 \mathrm{~mm}$, and the screw pitch (p) $7 \mathrm{~mm}$. The shift tip was termination at $45 \%$ to aid in keying during installation. Two piles groups $(1 \times 2$ and $2 \times 1)$ were used in this study with three spacing between piles $(1.5,3$, and 4.5$) \mathrm{Dh}$ where $\mathrm{Dh}$ is the diameter of the helix. The dimension of the pile groups is $(14 \times 5) \mathrm{cm},(11 \times 5) \mathrm{cm}$, and $(8 \times 5) \mathrm{cm}$ for spacing $(4.5,3$, and 1.5$)$ Dh respectively. The pile cap is manufactured from solid steel with a thickness of $6 \mathrm{~mm}$ as shown in Fig.1.

\section{Testing Procedure}

Preparation of Soil. The soil used in this study consists of soft clay and stiff clay in two layers put in a cylindrical container. Stiff clay with a thickness of $40 \mathrm{~cm}$ used in the bottom of the container which is compacted in eight layers has an undrained shear strength of $111 \mathrm{kN} / \mathrm{m}^{2}$ and a water content of $22 \%$. The upper layer consists of soft clay with a thickness of $20 \mathrm{~cm}$ and compacted with four layers, has an undrained shear strength of $38 \mathrm{kN} / \mathrm{m}^{2}$, and a water content of $29 \%$. The soil model was chosen for this study to represent the soil of southern Iraq relatively, especially Basra, whose soil is mostly composed of soft clay extending into stiff clay $[16,24]$. 

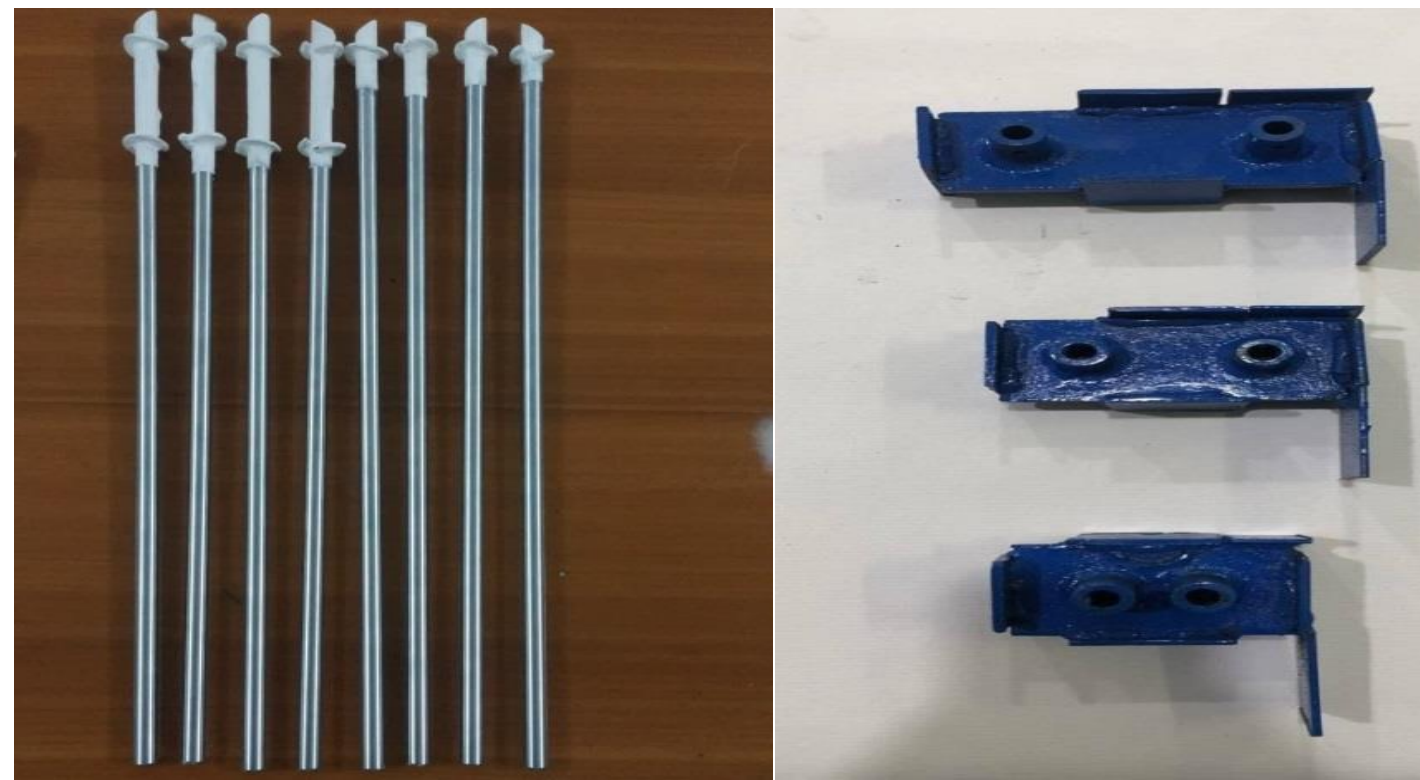

Figure 1. Pile and pile cap type used in model.

Pile Installation Process. After completing the soil preparation process, the container is inserted into the installation device and the steel holder is installed over the upper edge of the container and fixed the pile into the circular plate an inner diameter of 11 and the outer diameter of $25 \mathrm{~mm}$ to adjust the distances between piles. After that piles were screwed into the model of soil to the depth of $400 \mathrm{~mm}$ by using torque (T) applied by hydraulic torque motor with downward force (N) as shown in Fig. 2. The installation of the piles by using the torque affects the carrying capacity of the piles. To reduce the installation effect, the downward speed and the number of revolutions per minute are chosen depending on the pitch of the helix for the screw pile [25].

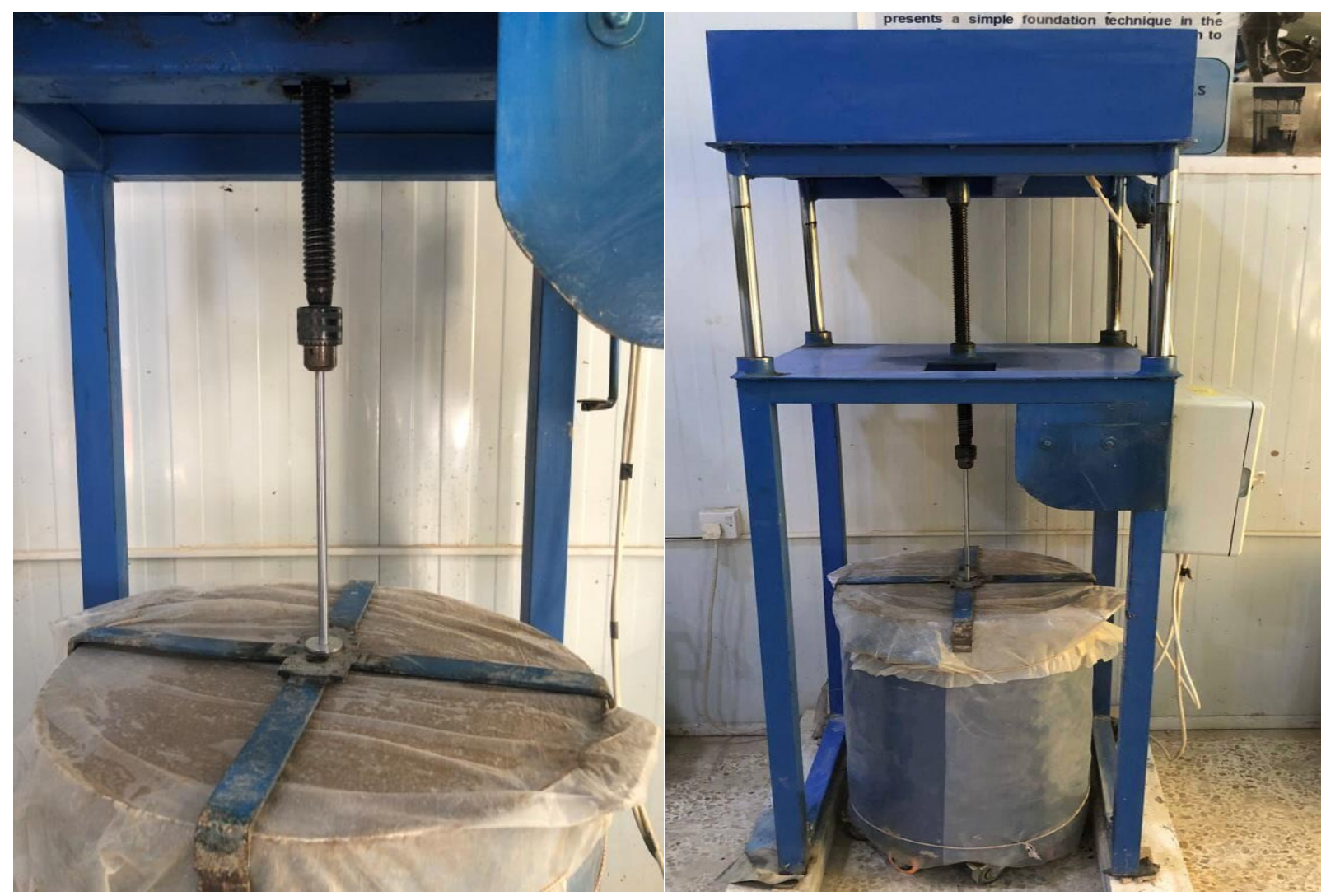

Figure 2. Pile installation device. 
The screw pile should be installed so that the pile enters the earth in an amount equivalent to the pitch (p) for the helix for every full turn in the direction to lessen the earth disturbance [26]. Therefore, the penetration rate of $(7 \mathrm{~mm} / \mathrm{min})$ and speed rotational of $(2.5 \mathrm{rpm})$ is used in all tests. After the first pile complete install, turn off the device and separate the shaft from the pile and the container rotated to install the second pile in the group. In this way, we complete the installation of the pile group in a container.

Piles Group Test. After completing the install of the pile's group, the container was put into the test device and fixed from the side by four stabilizers to prevent movement during the test as shown in Fig. 3. The study included two stages:

1) The first stage included finding the maximum lateral capacity for each group. Based on Brom's failure criteria the ultimate lateral capacity takes at the deflection equal to $20 \%$ [27]. In this study, the capacity was taken equal to the load corresponding to lateral deflection equal to 20 $\%$ from the helix diameter for comparison between screw groups.

2) In the second stage of the test, the two ways symmetry cyclic load applies in the sides of a cap of piles group in the different cyclic load ratio (CLR) by using two load cells as shown in Fig. 3 . The cyclic load ratio is taken as the ratio between the cyclic load magnitude to the ultimate static lateral capacity of the pile's group [28]. For this study, the ultimate static load for the group $(1 \times 2)$ of spacing $1.5 \mathrm{Dh}$ is chosen to find the cyclic load ratio because it gave the least value. Frequency $(0.2 \mathrm{~Hz})$ used in all tests, which is an example of the environmental frequency that range from $0-1 \mathrm{~Hz}$ [29], with different CLR $(0.2,0.5$, and 0.8). The results are expressed in the load-deflection curve after a number of cyclic equal to 100. The test was performed without the influence of vertical load to understand the lateral cyclic capacity.

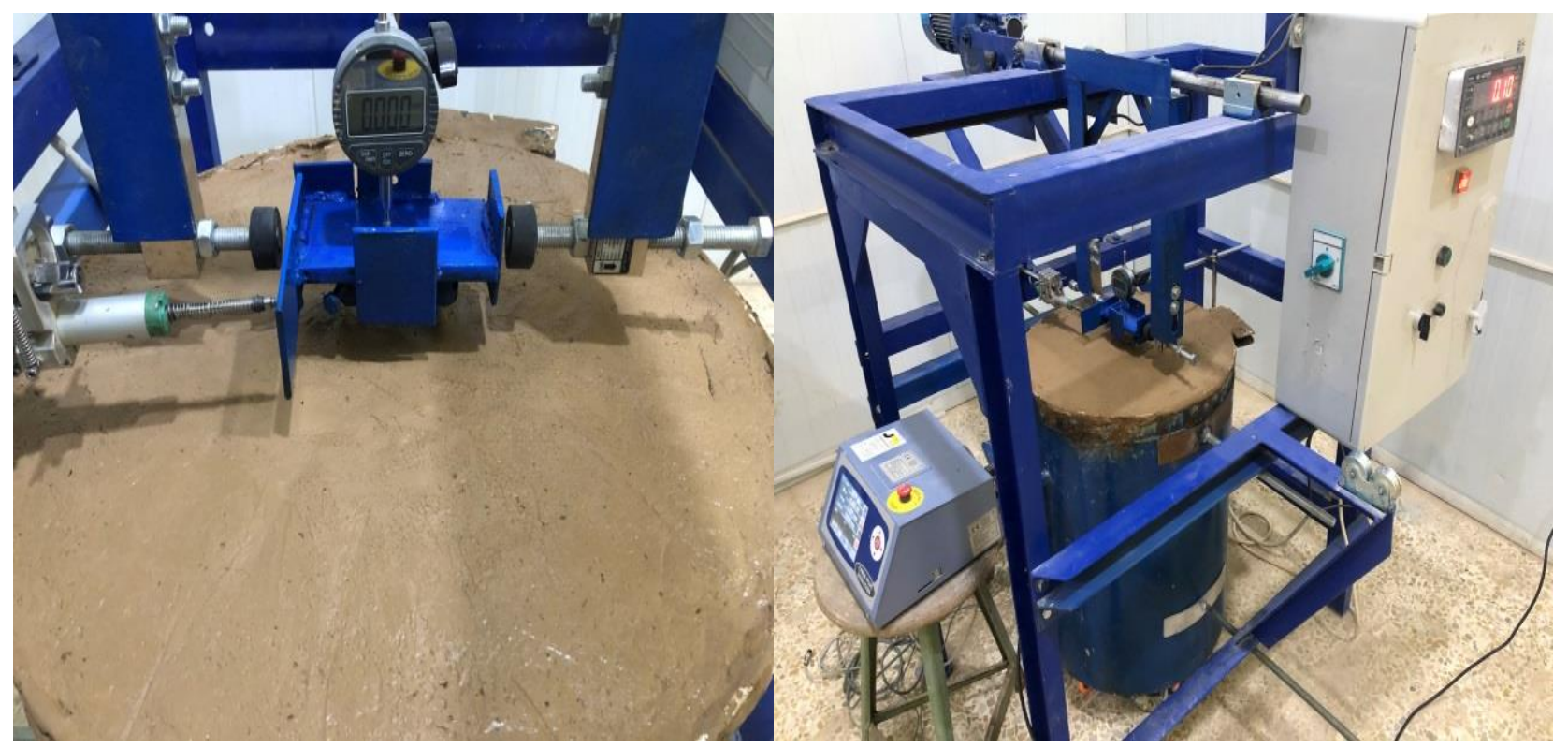

Figure 3. The test device for a cyclic lateral load.

\section{Results and Discussion}

Effect of Spacing on Piles Group. The load-deflection curve for screw piles group model $(1 \times 2)$ and $(2 \times 1)$ under cyclic lateral load with three spacing (1.5, 3, and 4.5) Dh at 100 number of cyclic are shown in Fig. 4 and 5. It is clear from these figures that the piles group with spacing 1.5Dh gave large deflection, while the group with spacing (3 and 4.5) Dh gave less deflection. The decrease in deflection with an increase in spacing between pile is due to the interaction effect (i.e. shadow effect) as a result of overlapping in stress zones. For small spacing in pile group under lateral cyclic load, 
block failure mode occur due to large overlap in stress between piles causes disturbed and softens the soil between piles. Therefore, lateral resistance decreases in the group with a small distance between the piles. In this study, the average increment of the lateral capacity of piles group with spacing (3 and 4.5) Dh compared with spacing 1.5Dh for single and double helix pile after 100 cyclic is shown in the Table 2.

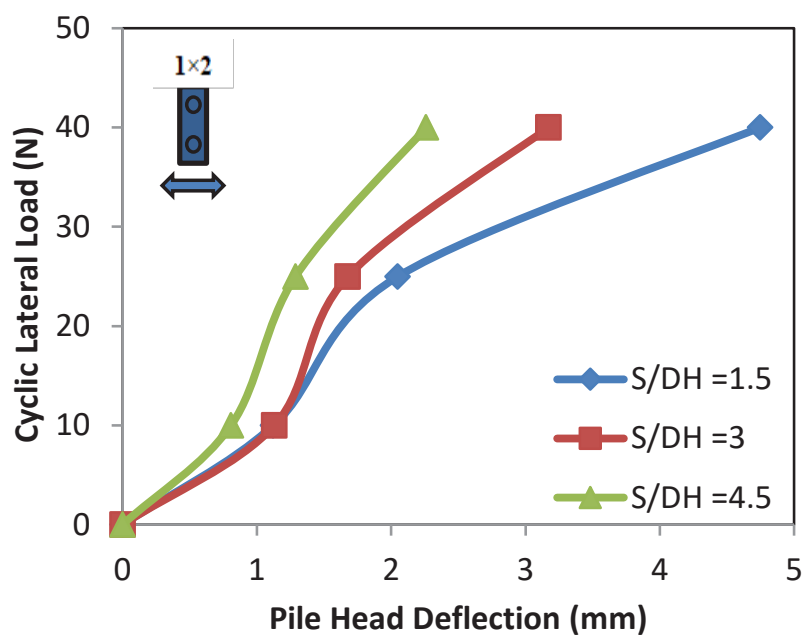

(a)

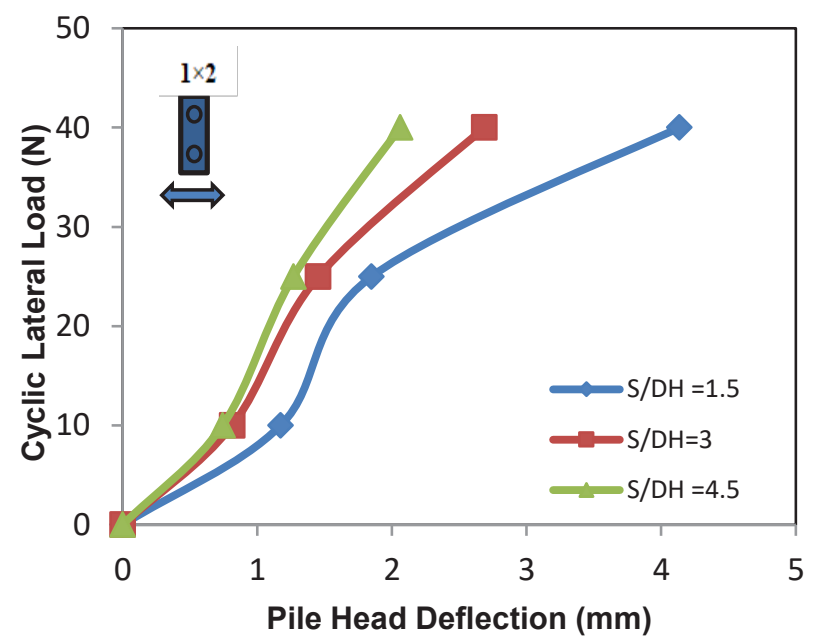

(b)

Figure 4. Effect of spacing between pile at piles group model $(1 \times 2)$ after100 number of cyclic. (a) Single helix, (b) Double helix.

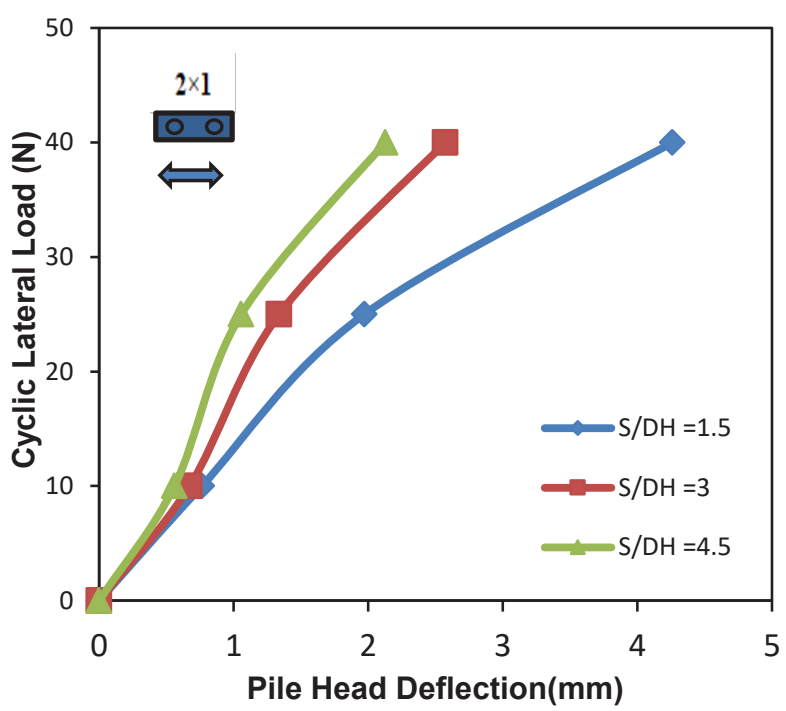

(a)

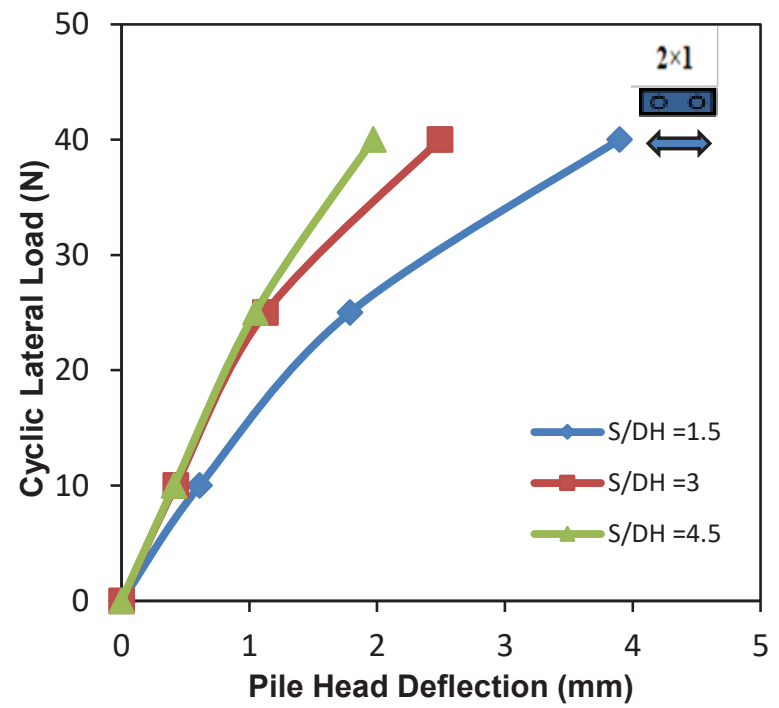

(b)

Figure 5. Effect of spacing between pile at piles group model $(2 \times 1)$ after 100 number of cyclic. (a) Single helix, (b) Double helix.

Table 2 Effect of pile spacing on lateral resistance of the screw pile group.

\begin{tabular}{|c|c|c|c|}
\hline \multirow{2}{*}{ Piles group model } & \multirow{2}{*}{ S/DH } & \multicolumn{2}{|c|}{ \% Increasing in lateral resistance } \\
\cline { 2 - 4 } & & Single helix & Double helix \\
\hline \multirow{2}{*}{$1 \times 2$} & 3 & $33 \%$ & $35 \%$ \\
\cline { 2 - 4 } & 4.5 & $52 \%$ & $50 \%$ \\
\hline \multirow{2}{*}{$2 \times 1$} & 3 & $39 \%$ & $36 \%$ \\
\cline { 2 - 4 } & 4.5 & $50 \%$ & $49 \%$ \\
\hline
\end{tabular}

Effect of Piles Group Configuration. The pile arrangement in two configurations $(1 \times 2)$ and $(2 \times 1)$ are carried out in this study by using three spacing $(1.5,3$, and 4.5) Dh with single and double helix as shown in Fig. 4 and 5. It is noticed from these figures that the arrangement of the pile at the same number in the group effect lateral response. The increase of pile number in the direction of load, 
increase the lateral resistance in the group. The result in this study showed that the lateral resistance of the single helix group $(2 \times 1)$ is larger than $(1 \times 2)$ about $11 \%$ and for the double helix about $6 \%$. This is maybe due to in a group $(2 \times 1)$ two-row of piles in the direction of lateral cyclic load and the factor affecting lateral bearing capacity is the interfering stresses between the front and back piles, and the soil between the two piles positively affects the increase in lateral resistance, while in the group $(1 \times 2)$ side to side pile, The influencing factor is the overlap of shear stresses between the two adjacent piles and that the soil between the two piles does not affect the increase in lateral resistance. which leads to that the group of $(1 \times 2)$ response as a single pile under lateral cyclic load. This result agrees with the work presented by $[21,30]$.

Effect of Number of Cycles and Cyclic Load Ratio on Screw Pile Group. Figure 6 shows the loaddeflection of the pile head for a group $(1 \times 2)$ with $\mathrm{S} / \mathrm{Dh} 1.5$ single helix at a different number of cyclic. The figure shows the nonlinear behavior of load-pile head deflection curves at a different number of cyclic. The nonlinear behavior increases in the cyclic 100 from cyclic one, this behavior is related to degradation in stiffness of the soil due to increase pore pressure and increase the gap between the soil and pile in the surface of soil [31]. Fig.7 and 8 show the deflection of pile head with a number of cyclic of the group $(1 \times 2)$ and $(2 \times 1)$ for three spacing $1.5,3$, and $4.5 \mathrm{Dh}$ at cyclic load ratio $0.2,0.5$, and 0.8 . The average increase in head deflection between cycle 1 and cycle 100 For cyclic load ratio $0.2,0.5$, and 0.8 about 23,26 , and $33 \%$ respectively for all the group and this average increase in a group with spacing 1.5 Dh greater than spacing 3 and $4.5 \mathrm{Dh}$. The increase of head deflection is mainly due to the increase of the gap between the piles and soil which leads to a decrease of lateral resistance of the soil. through the results, we also note that at the cyclic load ratio of 20 and $50 \%$, the lateral deflection increases gradually with the increase in the number of cyclic. As for the cyclic load ratio of $80 \%$, there is a significant increase in the lateral deflection at the first cyclic. This large deviation is due to the decrease in the passive resistance of clay at high cyclic loads. The critical cyclic load was defined as the load that causes a dramatic increase in deflection [28]. In this study, the critical load at the cyclic load ratio $80 \%$.

Effect the Number Helix of Pile. From the results shown in figures 5 and 6, the screw pile of the double helix gives an increase in lateral resistance about $5-10 \%$ from a pile of the single helix in all groups. Through the results, we notice that the effect of the number of helixes is variable, this variant may be due to disturbance in the soil during the pile's installation. This increase in lateral resistance increases with time due to improving the shear resistance of the soil around the screw pile after stabilization [32].

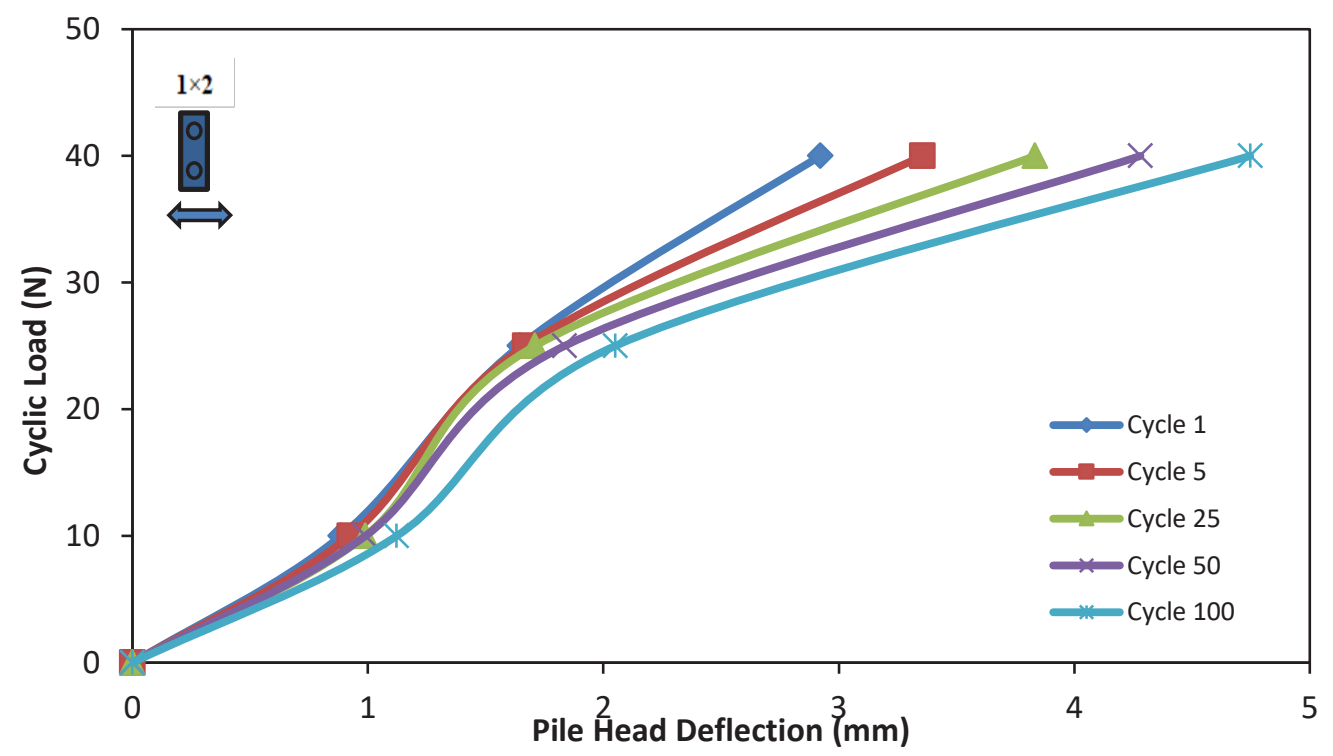

Figure 6. Load-Deflection curve of the group $(1 \times 2)$ with $\mathrm{S} / \mathrm{Dh}=1.5$, single helix at a different number of cycles. 


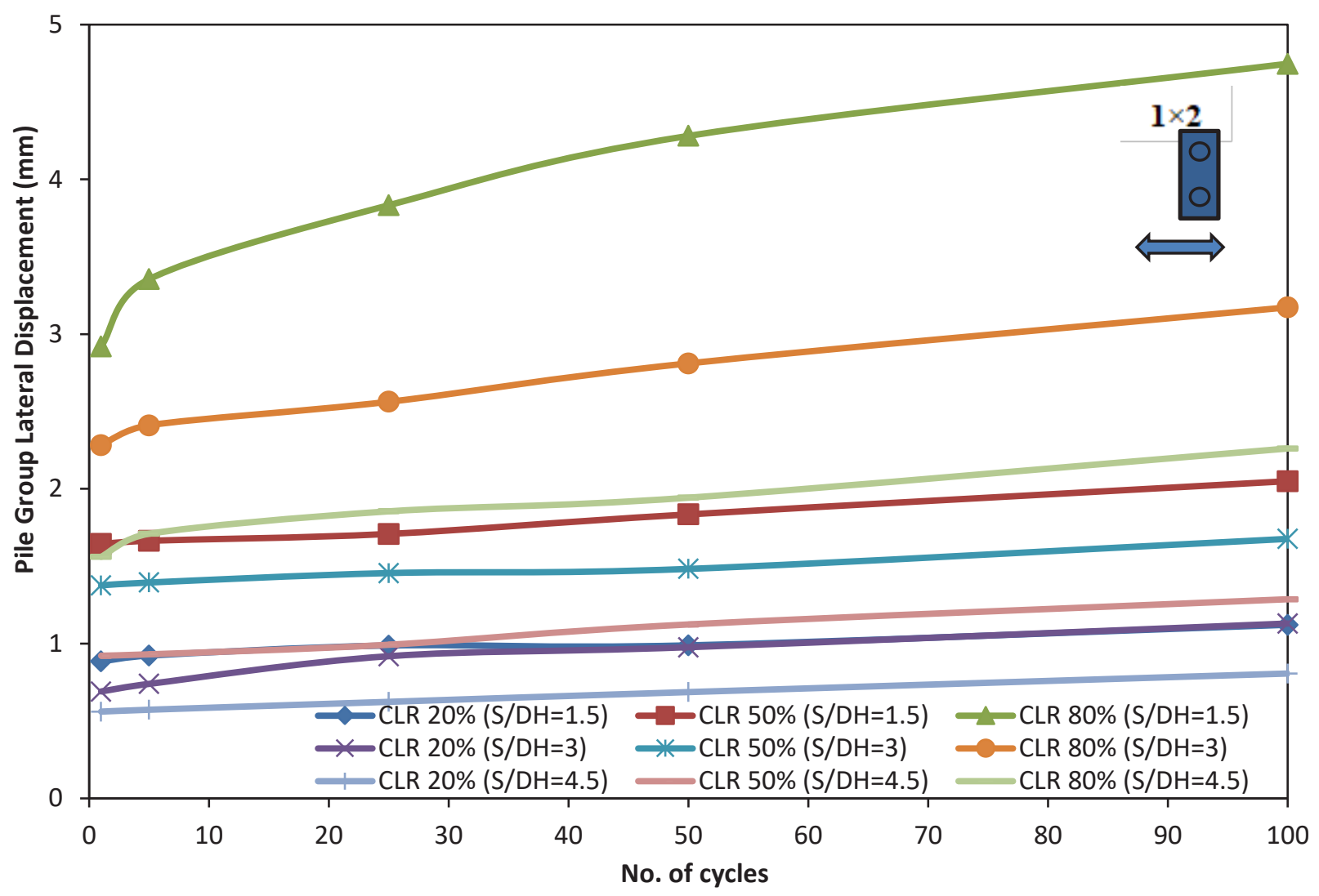

(a)

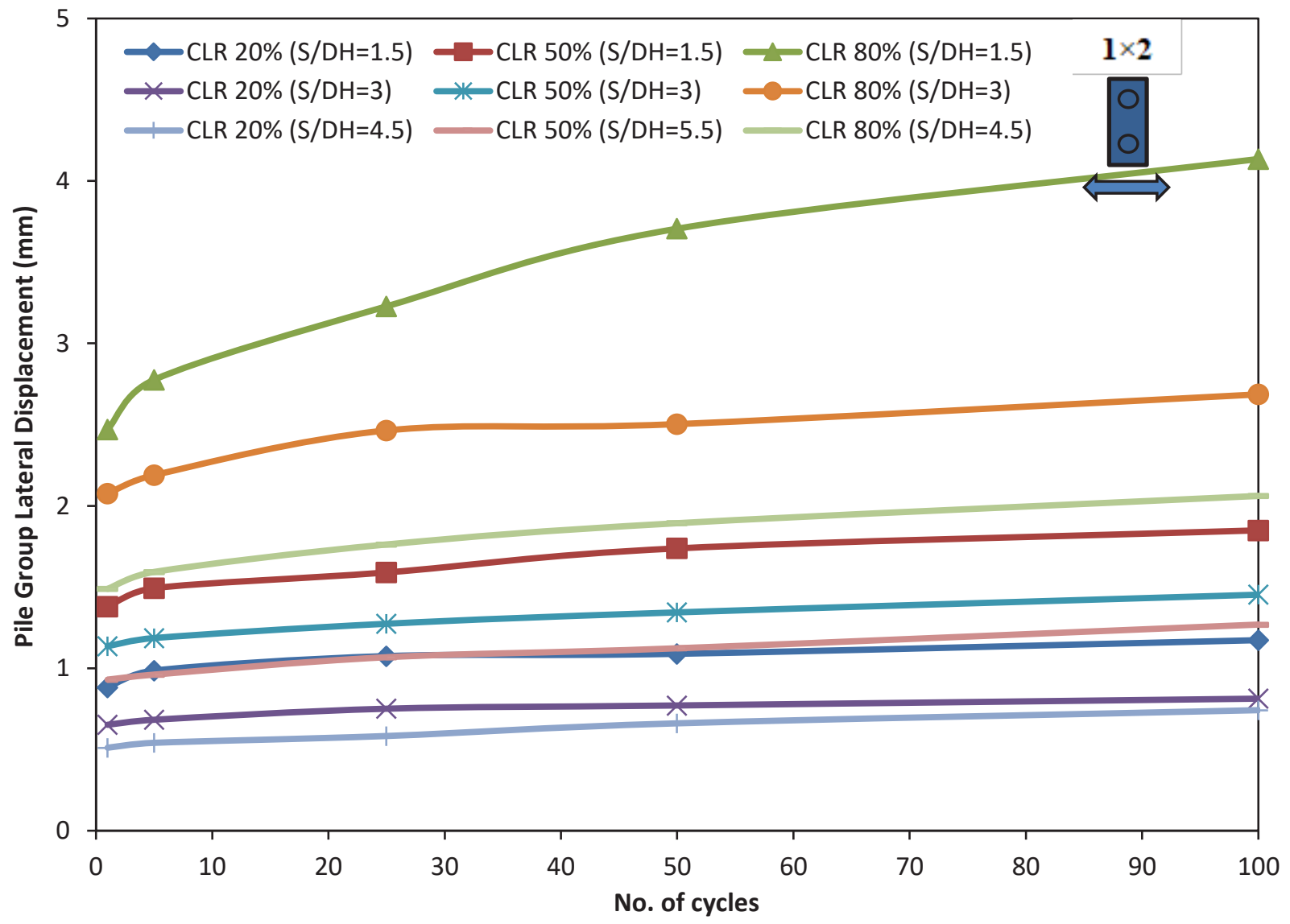

(b)

Figure 7. Deflection with the number of cycles for piles group model $(1 \times 2)$ with different spacing. (a) Single helix, (b) double helix. 


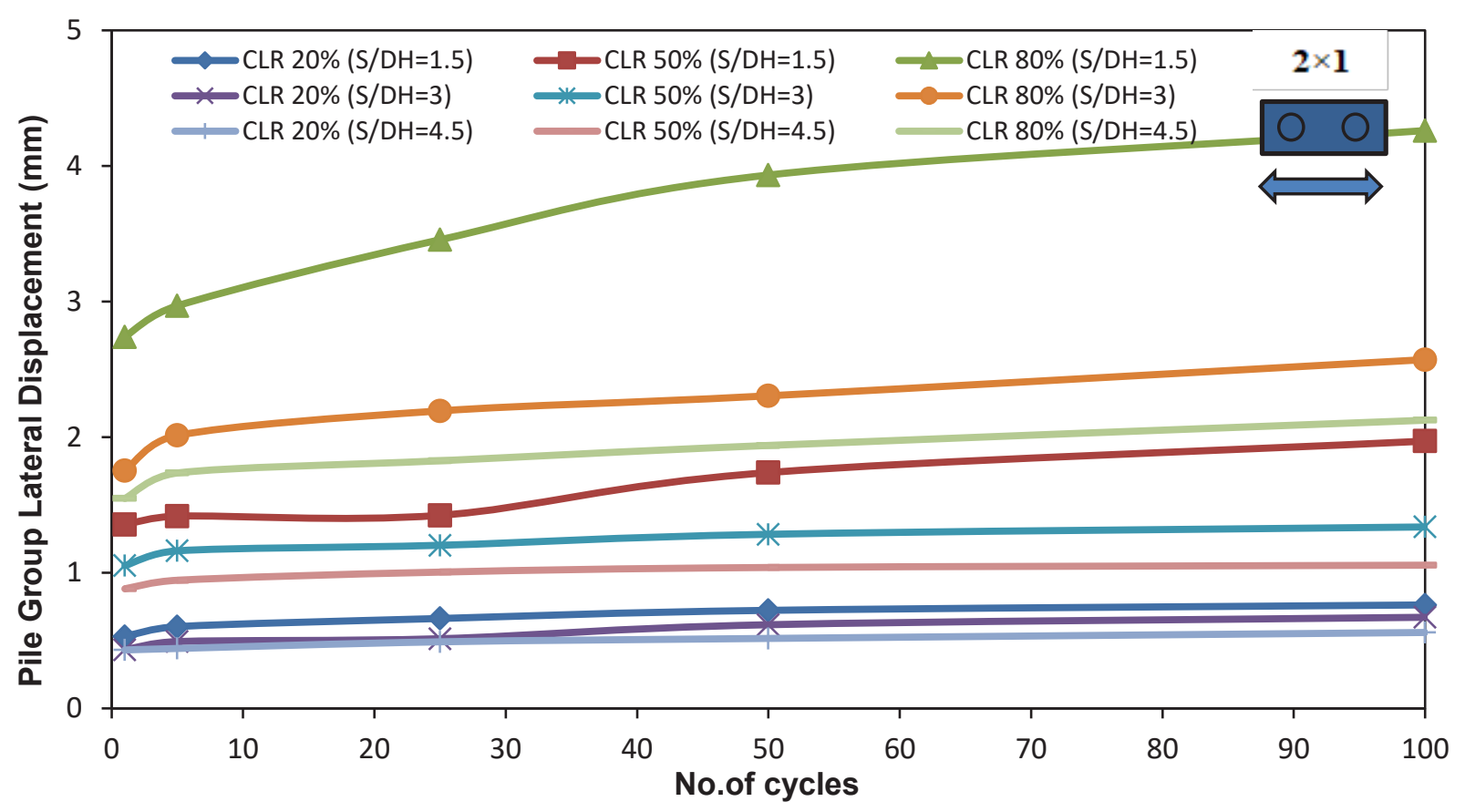

(a)

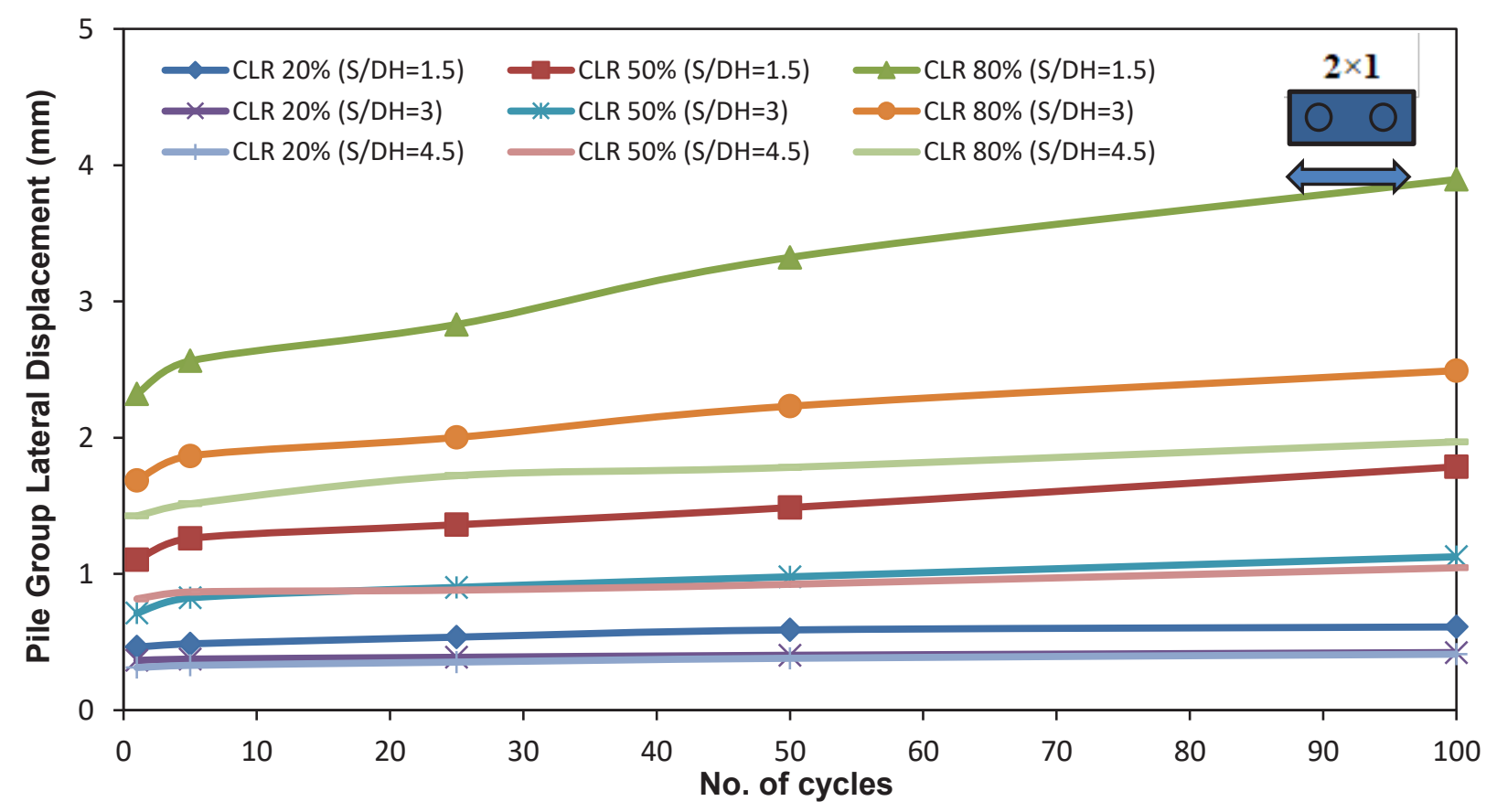

(b)

Figure 8 . Deflection with the number of cycles for piles group model $(2 \times 1)$ with different spacing. (a) Single helix, (b) double helix.

\section{Conclusions}

Based on the results of the tests, the following conclusions can be drawn out:

- The spacing between screw piles have an important influence on the lateral resistance of piles group, the increase in spacing between pile reduces the lateral deflection in the same load.

- The arrangement of the same number of piles in the group affects the lateral resistance, the increase of pile in the direction of the cyclic load increases the lateral resistance more than the increase of pile number in the first row of the pile's group.

- The group of spacing 1.5 Dh greater affected in the increase of a number of cyclic from the group of spacing 3 and $4.5 \mathrm{D}$. 
- The pile head deflection increases with an increased cyclic load ratio due to the gap between the pile and soil and increases the depth of the gap from the surface.

- The increase in the number of cyclic increases the pile head deflection because of the degradation in stiffness of the soil and reduced soil shear strength.

- The increase in the number of cyclic causes an increase in the porewater pressure in areas close to the pile and leads to a decrease in the shear strength of the soil.

- The lateral resistance increases with an increase in the number of helixes.

\section{References}

[1] M. A. Sakr, A. K. Nazir, W. R. Azzam, A. F. Sallam, 2016. Behavior of grouted single screw piles under inclined tensile loads in sand. EJGE, 21(2016): 572-591.

[2] B. W. Byrne, G. T. Houlsby, 2015. Helical piles: an innovative foundation design option for offshore wind turbines. Philosophical Transactions of the Royal Society A: Mathematical, Physical and Engineering Sciences, 373(2035), p.20140081.

[3] K. M. Tappenden and D.C. Sego, 2007. Predicting the axial capacity of screw piles installed in Canadian soils. In the Canadian Geotechnical Society (CGS), OttawaGeo2007 Conference (pp. 1608-1615).

[4] M. Sakr, 2010. Lateral resistance of high capacity helical piles: case study. In: Proceedings of the 63rd Canadian Geotechnical and 6th Canadian Permafrost Conference. Calgary, Alberta, 402412.

[5] Y. Türedi and M. Örnek, 2020. Analysis of model helical piles subjected to axial compression. Journal of the Croatian Association of Civil Engineers, 72(09), 759-69.

[6] Z. Li, S. K. Haigh, M.D. Bolton, The response of pile groups under cyclic lateral loads. International Journal of Physical Modelling in Geotechnics. 10(2) (2010) 47-57.

[7] Y. V. Prasad and S. N. Rao, 1996. Lateral capacity of helical piles in clays. Journal of Geotechnical Engineering, 11, 938-941.

[8] S. Mittal, B. Ganjoo, and S. Shekhar, 2010. Static equilibrium of screw anchor pile under lateral load in sands. Geotechnical and Geological Engineering, 5, 717-725.

[9] H. Ding, L. Wang, P. Zhang, and C. Le, 2018. Study on the lateral bearing capacity of singlehelix pile for offshore wind power. In ASME 37th International Conference on Ocean, Offshore and Arctic Engineering, 1-6.

[10] F. M. Abdrabbo and El A. Z. Wakil, 2016. Laterally loaded helical piles in sand. Alexandria Engineering Journal, 4, 3239-3245.

[11] M. Sakr, 2009. Performance of helical piles in oil sand. Canadian Geotechnical Journal, 9, 10461061.

[12] M. A. Elkasabgy and M. H. El Naggar, 2015. Lateral performance of large-capacity helical piles. In IFCEE 2015 International Association of Foundation Drilling Deep Foundation Institute Pile Driving Contractors Association, American Society of Civil Engineers.

[13] T. A. Al-Baghdadi, M. J. Brown, J. A. Knappett, and A. H. Al-Defae, 2017. Effects of vertical loading on lateral screw pile performance. Proceedings of the Institution of Civil EngineersGeotechnical Engineering, 3, 259-272.

[14] H. O. Abbas and O. K. Ali, 2020. Comparing the axial performance of screw pile with ordinary piles in soft clay layer overlaying sandy soil. Lecture Notes in Civil Engineering, 112.

[15] H. O. Abbas and O. K. Ali, 2020. Parameters affecting screw pile capacity embedded in soft clay overlaying dense sandy soil. IOP Conference Series: Materials Science and Engineering. 745:012117.

[16] A. S. Jamill and H. O. Abbas, 2020. Compressive capacity of triangular screw piles group embedded in soft clay. Diyala Journal of Engineering Sciences, 13(4), 44-9.

[17] O.J. Mukhlef, M, O, Karkush, and A. Zhussupbekov, 2020. Strength and compressibility of screw piles constructed in gypseous soil. IOP Conference Series: Materials Science and Engineering, 901:012006. 
[18] M. O. Karkush, 2016. Behavior of pile groups subjected to axial static and lateral cyclic loads in contaminated soils. In Geo-China (2016), 166-174.

[19] M. O. Karkush, 2016. Impacts of soil contamination on the response of piles foundation under a combination of loading. Engineering, Technology \& Applied Science Research, 6(1), 917-922.

[20] A. K. Mahmood and J. M. Abbas, 2019. The effect of vertical loads and the pile shape on pile group response under lateral two-way cyclic loading. Civil Engineering Journal, 5(11), 2377-91.

[21] A. W. Saleh, J. M. Abbas, 2020. Effect of spacing and cross-sectional shape on piled raft system subjected to lateral cyclic loading. Diyala Journal of Engineering Sciences, 13(3), 114-122.

[22] British Standard, BS, 1986. Code of Practice for Foundations. British Standard Institution, London, British, C.P. 8004.

[23] S. Basack and S. Nimbalkar, 2018. Measured and predicted response of pile groups in soft clay subjected to cyclic lateral loading. International Journal of Geomechanics, 18(7), 04018073.

[24] A. J. Al-Taie, 2015. Profiles and Geotechnical Properties for some Basra Soils, Al-Khwarizmi Engineering Journal, 11(2), 74- 85.

[25] T. A. Al-Baghdadi, C. Davidson, M. J. Brown, J. A. Knappett, A. Brennan, C. Augarde, W. Coombs, L. Wang, D. Richards, and A. Blake. 2018. CPT-based design procedure for installation torque prediction for screw piles installed in sand. Offshore Site Investigation Geotechnics 8th International Conference Proceedings (n.d.), 346-353.

[26] A. Mohajerani, D. Bosnjak, D. and D. Bromwich, 2016. Analysis and design methods of screw piles: a review. Soils and Foundations, 56(1), 115-128.

[27] B. B. Broms, 1964. Lateral resistance of piles in cohesive soils. Journal of the Soil Mechanics and Foundations Division, b. 90(2), 27-64.

[28] H. G. Poulos, 1982. Single pile response to cyclic lateral load. J. Geotech Eng. 10 (3), 355-37

[29] J. R. Peng, B. G. Clarke, and M. Rouainia, 2006. A device to cyclic lateral loaded model piles. Geotechnical Testing Journal, 29, 341-347.

[30] B.S. Albusoda, A.F. Alsaddi, 2017. Experimental study on performance of laterally loaded plumb and battered piles in layered sand. Journal of Engineering, 23(9), 23-37.

[31] S. Chandrasekaran, A. Boominathan, G. Dodagoudar, 2010. Experimental investigations on the behavior of pile groups in clay under lateral cyclic loading. Geotechnical and Geological Engineering, 28(5), 603-617.

[32] C.N. Weech, J.A. Howie, 2012. Helical piles in soft sensitive soils-a field study of disturbance effects on pile capacity. In VGS Symposium on Soft Ground Engineering. 